\title{
Digital Technologies as a Factor in the Promotion of Smart City Leadership
}

\author{
Evgeny Popov \\ Institute of Economics \\ Ural Branch of the Russian Academy of Sciences \\ Moskovskaya str. 29, 620014 Yekaterinburg \\ Ural Federal University \\ Mira str. 19, 620002Yekaterinburg \\ Russian Federation \\ e-mail: epopov@mail.ru \\ Konstantin Semyachkov \\ Institute of Economics, Ural Branch of the Russian Academy of Sciences \\ Moskovskaya str. 29, 620014 Yekaterinburg \\ Ural Federal University, \\ Mira str. 19, 620002 Yekaterinburg \\ Russian Federation \\ e-mail: k.semyachkov@mail.ru \\ Galina Popova \\ Ural Federal University \\ Mira str. 19, 620002 Yekaterinburg \\ Russian Federation \\ e-mail: galka3099@gmail.com
}

\begin{abstract}
This work set out to investigate the effects of digital technologies on urban environment in the process of smart city formation. In particular, the study was focused on the promotion of smart city leadership, as well as economic relations that emerge in the process of smart city formation and produce socioeconomic effects. The research methodology involved a bibliographic study of available publications on smart cities, as well as a logical and systemic modelling of the revealed effects on the basis of the authors' previous research into various aspects of smart city formation. The conducted analysis of recent publications revealed the main characteristics of the smart city formation process, which involve vast application of social and technological drivers of the digital society development. The social and economic effects of smart city formation were determined and generalized with respect to the volume of implemented digital technologies. The waves of technological innovations in the process of smart city formation were determined, including the formation of a basis for data exchange, the development of social networking services and the implementation of artificial intelligence devices. In addition, the chronological sequence of manifestation of social and economic effects of smart city formation was defined.
\end{abstract}

\section{Introduction}

Issues associated with territory development based on the principles of sustainability are increasingly attracting research interest. The widespread application of digital technologies, which are considered to be an important condition for territory development, is transforming the fundamental principles of urban formation. A new approach has been gaining recognition recently, which postulates that digital technologies increase the efficiency of private and public sectors by enabling citizens to acquire access to higher-quality goods and services (Joia and Kuhl 2019).

The problem of implementing digital technologies in urban areas has been gaining importance in recent years (Zlyvko et al. 2014; or Lisin et al. 2018). Considerable scientific attention has been paid to the idea of making cities smarter through the advantages of the digital era. Today, various projects aimed at implementing digital technologies for the development of urban areas have been carried out in Europe, North America, and Asia (Niño-Amézquita eta al. 2017). In addition, smart cities possess a significant potential to promote sustainable growth in emerging and transforming economies (Strielkowski 2019). It is known that the innovative potential of cities determines their international competitiveness, which factor underpins fundamental urban 
transformations. The rapid development of digital technologies transforms cities into megalopolises with a significant digital potential (Popov and Semyachkov 2018).

Although a unified approach to the concept of smart city is yet to be developed, the smart city can be defined as a city that implements digital technologies to support sustainable growth and improved living standards. Through involving digital technologies in municipal services, cities become smarter in terms of managing resources. Such new types of cities create new opportunities for businesses and citizens, thus attracting private investments, highly qualified human capital and other resources (Paskaleva and Cooper 2019).

The smart city concept rests on the implementation and deployment of digital technology infrastructures capable of supporting social and urban growth through improved economic processes, citizens' engagement and increased efficiency of government administration. The initiatives aimed at developing smart cities cover, as a rule, such directions, as economic growth, social mobility, environment, living standards and city administration. Despite the growing number of studies into various aspects of smart city formation, few publications have analysed the efficiency of smart city initiatives, as well as identified a range of problems that smart cities encounter.

In general, the smart city concept is a new model created on the basis of conventional knowledge of urban environment development. This is a type of urban environment based on vast application of new generation digital technologies. It embraces tools and solutions for improving the social environment management and government administration transformation. Smart cities imply innovative application of digital technologies together with transformation and development of urban environment and public consciousness, which is crucial for sustainable development of modern cities.

Despite the significant attention paid to the questions of smart city development, no versatile approach has thus far been developed to measure urban environment development under the conditions of digitalization and evaluate the impact of digital technologies on smart city leadership. Therefore, the objective of this study was to determine the effects of digital technologies on urban socioeconomic environment in the promotion of smart city leadership.

Such concepts as "smart city", "digital city" and "informational city" are sometimes used interchangeably, thereby causing confusion. In fact, the concept of the smart city can include the digital city, in which case the smart city concept implies integrated management of information that creates value through applying cutting-edge technologies for searching, accessing, transferring and processing data. However, the concept of the digital city appears to be narrower in comparison with the concept of the smart city. Digital cities are focused on either electronic delivery of certain services or infrastructure improvement, rather than complex administration of city functions, such as public utilities, transportation and the like (Rabari and Storper 2014).

The smart city concept can embrace aspects not directly related to the operational governance of the city. A typical approach is to ensure economic and social development based on digital technologies to encourage progress, solve social issues, preserve and develop culture. Meanwhile, the existing cities with historically well-developed infrastructures and administrative systems require a more moderate, gradual approach to modernization. The following key foci of modernization contributing to the development of smart cities can be distinguished: governance; finance; business-models; smart city services; institutional environment. Today, the questions of how to develop and manage smart cities are increasingly being tackled following networking approaches.

\section{Methodology}

In this study, we addressed the question of how smart cities form leadership positions and which economic relations underpin this process, thereby producing social and economic effects. The research methodology involved a bibliographic analysis of available publications on smart cities, as well as a logical-systemic modelling of the revealed effects on the basis of the authors' previous research into smart city formation. The research algorithm included the following steps:

- $\quad$ bibliographic selection of publications related to smart cities using the Scopus and WoS abstract and citation databases;

- content analysis of the selected publications to reveal common trends;

- identification of social and economic effects of smart city formation;

- generalization of the determined social and economic effects of smart city formation;

- determination of hierarchical relations between the revealed social and economic effects.

A bibliographic search across the Scopus and WoS databases was performed using the following key words: "smart city development", "smart city effectiveness", "smart city effects", "smart city concept", "smart city cases", "economics of smart cities", "social effects of smart cities", "smart city governance". The selected publications (165) were divided into three groups: theoretical concepts of smart city formation, practical 
experience of implementing the smart city concept (cases), effects of smart city development. Subsequently, a content analysis was carried out to reveal social and economic effects of the smart city development - both theoretical (perceived) and actually achieved, as well as potential risks. Finally, the indicated effects were generalized to demonstrate hierarchal relations between them.

\section{Results and Discussion}

The research results showed the following social and economic effects of smart city formation. The effects were organized according to the extent (volume) of implementation of digital technologies (see Table 1).

Table 1. Social and economic effects of smart city formation

\begin{tabular}{|c|c|}
\hline $\begin{array}{l}\text { Type of technological innovations implemented or proposed } \\
\text { for implementation }\end{array}$ & Attained and expected effects \\
\hline $\begin{array}{l}\text { Platform for managing large information flows in a smart city } \\
\text { based on geoinformational systems (GIS) and advanced } \\
\text { achievements in virtual reality (VR). WebVRGIS system } \\
\text { effectiveness was tested in Shenzhen (China). The uniqueness } \\
\text { of the approach was in integrating data from various sources } \\
\text { including traffic detectors both in land and underground spaces, } \\
\text { data from individuals (Lv et al. 2016). }\end{array}$ & $\begin{array}{l}\text { It was shown that the speed of navigation in the city } \\
\text { increased significantly. The WebVRGIS application } \\
\text { enabled the effectiveness of certain institutions (police } \\
\text { and ambulance) to be improved. }\end{array}$ \\
\hline $\begin{array}{l}\text { The IoT (Internet of Things) architecture in Padova (Italy) and } \\
\text { the prospects of its functioning were analysed. At the time of } \\
\text { the research, the system included more than } 300 \text { sensory units, } \\
\text { which collected data about air pollution, humidity, levels of } \\
\text { exhaust gas pollution, etc. The data were processed and } \\
\text { transferred to a specialized municipal department (Zanella et al. } \\
\text { 2017). }\end{array}$ & $\begin{array}{l}\text { An important economic effect was a decrease in the } \\
\text { costs of lighting maintenance (lamp replacement, } \\
\text { repairs of the networks). }\end{array}$ \\
\hline $\begin{array}{l}\text { In a number of cities, smart web-portals allowing a user to get } \\
\text { information (frequently represented visually) in a single place } \\
\text { were created. The portals exhibit the characteristics of digital } \\
\text { virtual spaces for communication between citizens and virtual } \\
\text { personnel (robots answering questions) (Komninos et al. 2018). }\end{array}$ & $\begin{array}{l}\text { It was noted that virtual digital spaces encourage the } \\
\text { formation of "healthy social ecology" in a city, which } \\
\text { is expressed in improved logistics, increased level of } \\
\text { public security (public alerts), reduced unemployment } \\
\text { (through availability of information on jobs). }\end{array}$ \\
\hline $\begin{array}{l}\text { Measures directed at encouraging citizens' initiatives, both } \\
\text { social and economic, through: } \\
\text { - creating city forums in social networking sites; } \\
\text { - creating mobile applications for solving specific city issues; } \\
\text { - creating cloud technologies for data storage and processing. }\end{array}$ & $\begin{array}{l}\text { The effects of such innovations include: } \\
\text { - encouraging crowdsourcing and crowdfunding for } \\
\text { solving citizens' pressing issues; } \\
\text { - job creation; } \\
\text { - active knowledge-sharing; } \\
\text { - incentive for civil society development; } \\
\text { - release of municipal resources as a result of applying } \\
\text { cloud technologies (obtaining documents, calculating } \\
\text { social benefits, etc.) (Carè et al. 2018; Kakderi et al. } \\
\text { 2016; Bergvall-Kåreborn and Ståhlbröst 2009). }\end{array}$ \\
\hline $\begin{array}{l}\text { The following perspective digital innovations for smart city } \\
\text { concept realization were suggested: } \\
\text { - implementation of artificial intelligence systems; } \\
\text { - usage of augmented reality devices; } \\
\text { - usage of technologies allowing to manage huge data sets on a } \\
\text { real time basis (Chen-Ritzo 2009). }\end{array}$ & $\begin{array}{l}\text { Expected effects of such innovations: } \\
\text { - self-learning systems based on artificial intelligence } \\
\text { recognize emerging patterns and trends in data arrays, } \\
\text { thus enabling real-time response; } \\
\text { - fundamental improvement of environmental } \\
\text { problems. }\end{array}$ \\
\hline $\begin{array}{l}\text { The effectiveness of implementing the following innovations } \\
\text { was analysed on the example of } 10 \text { megalopolises (Seoul, } \\
\text { Vienna, London, etc.): } \\
\text { - development of municipal programmes to facilitate the } \\
\text { transfer to the "smart city" category; } \\
\text { - creation of specialized applications for mobile devices; } \\
\text { - installation of sensors, detectors and other IoT elements; } \\
\text { - installation of detectors on dumpsters to detect their } \\
\text { overfilling; } \\
\text { - creation of the city's information portals (Anthopoulos 2017) }\end{array}$ & $\begin{array}{l}\text { The following effects were noted: } \\
\text { - a sharp increase in the number of freelancers in } \\
\text { digital industries; } \\
\text { - emergence of "smart" dumpsters which optimize } \\
\text { garbage collection; } \\
\text { - active development of car-sharing stations, some } \\
\text { traffic improvement; } \\
\text { - improvement of city infrastructure planning, } \\
\text { appearance of lots of parks; } \\
\text { - a decrease in budget spending on city functioning in } \\
\text { New York }\end{array}$ \\
\hline
\end{tabular}


The conducted bibliographic analysis allowed us to specify four main dimensions, the constituent elements of which produce various social and economic effects in the process of implementing the smart city concept. These effects include urban governance, infrastructure optimization, innovations in social institutions, as well as technological and economic innovations. It is established that the implementation of digital technologies in all spheres of a city's functioning does produce significant social and economic effects.

Therefore, it can be concluded that the implementation of digital technologies during the formation of smart city leadership entails certain positive effects. Moreover, these social and economic effects arise hierarchically, depending on when the respective digital technologies and innovative applications were implemented. The chronological sequence of social and economic effects includes the following consecutive stages: improvement of governance mechanisms; city infrastructure optimization; enhanced social institutions; development of social and economic innovations.

The novelty of this research consists in the systematization of social and economic effects of smart city formation in terms of the volume of implemented digital technologies. The defined stages of social and economic effects emerging during the formation of smart cities contribute to the theory of consecutive stages in building a digital society.

\section{Conclusions}

This study aimed at identification and generalization of social and economic effects created during implementation of digital technologies for the promotion of smart city leadership. In the course of the study, the following theoretical and practical results were obtained.

Firstly, specific features of the process of smart city formation were revealed on the basis of a bibliographic analysis of contemporary publications. These features involve a widespread application of social and technological drivers of the digital society development.

Secondly, social and economic effects of smart city formation were generalized in terms of the volume of implemented digital technologies.

Thirdly, waves of technological innovations during the formation of smart cities were distinguished. These include the formation of a basis for data exchange, the development of social networking services and the implementation of artificial intelligence devices.

Fourthly, a chronological sequence of the emergence of social and economic effects during smart city formation was determined: improvement of governance mechanisms; city infrastructure optimization; enhanced social institutions; development of social and economic innovations.

The obtained findings can be useful for the development of a theoretical basis for forecasting the development of smart cities. In addition, the results have a practical significance for elaboration of strategic development plans for smart cities.

\section{Acknowledgment}

The reported study was funded by RFBR according to the research project No. 18-00-00665.

\section{References}

Anthopoulos L (2017) Smart utopia VS smart reality: Learning by experience from 10 smart city cases. Cities 63:128-148. doi:10.1016/j.cities.2016.10.005

Bergvall-Kåreborn B, Ståhlbröst A (2009) Living Lab: An Open and Citizen-Centric Approach for Innovation. International Journal of Innovation and Regional Development 4(1):356-370. doi: 10.1504/IJIRD.2009.022727

Carè S, Trotta A, Carè R, Rizzello A (2018) Crowdfunding for the development of smart cities. Business Horizons 61(4):501-509. doi: 10.1016/j.bushor.2017.12.001

Chen-Ritzo CH, Harrison C, Paraszczak J, Parr F (2009) Instrumenting the Planet. IBM Journal of Research and Development, 53(3):338-353. doi: 10.1147/JRD.2009.5429014

Joia LA, Kuhl A (2019) Smart City for Development: A Conceptual Model for Developing Countries. In: Lecture Notes in Computer Science, Springer, Cham, pp. 203-214. doi:10.1007/978-3-030-19115-3_17

Kakderi C, Komninos N, Tsarchopoulos P (2016) Smart Cities and Cloud Computing: Lessons from the STORM CLOUDS Experiment. Journal of Smart Cities 2(1):4-13. doi: 10.18063/JSC.2016.01.002 
Komninos N., Kakderi C., Panori A., Tsarchopoulos P (2018) Smart City Planning from an Evolutionary Perspective. Journal of Urban Technology 1:1-18. doi: 10.1080/10630732.2018.1485368

Lisin E, Shuvalova D, Volkova I, Strielkowski W (2018) Sustainable development of regional power systems and the consumption of electric energy. Sustainability 10(4):1111. doi: 10.3390/su10041111

Lv Z, Li X, Zhang B, Wang W, Zhu Y, Hu J, Feng S (2016) Managing big city information based on webvrgis. IEEE Access 4:407-415. doi: 10.1109/ACCESS.2016.2517076

Niño-Amézquita J, Dubrovsky V, Jankurová A (2017) Innovations and competitiveness in regional development: a comparison of Latin America, Europe, and China. Czech Journal of Social Sciences, Business and Economics 6(1):28-36. doi: 10.24984/cjssbe.2017.6.1.4

Paskaleva K, Cooper I (2019) Innovations in Co-Created Smart City Services. Setting Foundations for the Creation of Public Value in Smart Cities, Springer, Cham, pp. 165-195. doi:10.1007/978-3-319-98953-2_7

Popov EV, Semyachkov KA (2018) Comparative analysis of the strategic aspects of the digital economy development. Perm University Bulletin. Series: Economy, 13(1):19-36

Rabari C, Storper M (2014) The digital skin of cities: urban theory and research in the age of the sensored and metered city, ubiquitous computing and big data. Cambridge Journal of Regions, Economy and Society 8(1):2742. doi:10.1093/cjres/rsu021

Strielkowski W. Social impacts of smart grids: the future of the smart grids and energy market design, $1 \mathrm{st}$ edn. (Elsevier, London, 2019), 342 p.

Zanella A, Bui N, Castellani A, Vangelista L, Zorzi M (2014) Internet of Things for Smart Cities. IEEE Internet of Things Journal 1(1):22-32. doi: 10.1109/jiot.2014.2306328

Zlyvko O, Lisin E, Rogalev N, Kurdiukova G (2014) Analysis of the concept of industrial technology platform development in Russia and in the EU. International Economics Letters 3(4):124-138. doi: 10.24984/iel.2014.3.4.2 